products in the United Kingdom, on the Continent, and in the United States; Mr. J. C. Morrison (Carron Company) to study melting, moulding and heat treatment of alloy cast irons, quality control of metal and sand plants in modern foundries, and new developments in related metallurgical processes; $\mathrm{Mr}$. T. Tait (Colvilles Limited) to study the technical and economic factors involved in the use of oxygen in steel industries in the United Kingdom, on the Continent, and in the United States and Canada.

The Mond Nickel Fellowships Committee is offering one-year fellowships valued at $£ 900-£ 1,200$ for 1959 , to graduates of British nationality to enable them to obtain wider experience and additional training in industrial establishments, in Britain or abroad, to make them more suitable for future employment in senior technical and administrative positions in British metallurgical industries. Applicants will be required to state details of the programme they wish to carry out. Particulars and forms of application are available from the Secretary, Mond Nickel Fellowships Committee, 4, Grosvenor Gardens, London, S.W.1.

\section{Mechanization of Thought Processes}

A symposium on "The Mechanization of Thought Processes" is being held at the National Physical Laboratory, Teddington, during November 24-27. More than two hundred delegates will be attending. After opening sessions on general principles, succeeding sessions will be devoted to automatic programming, language translation, speech recognition, learning in machines, and implications for biology and for industry. Further information can be obtained from the Chief Information Officer, Department of Scientific and Industrial Research, Charles House, 5-11 Regent Street, London, S.W.1.

\section{United Nations Conference on Peaceful Uses of Atomic Energy: Proceedings}

THE United Nations have announced that the prepublication period for the Proceedings of the Second U.N. International Conference on the Peaceful Uses of Atomic Energy, during which complete sets may be ordered at a special price, has been extended to January 31,1959 . The action was taken to facilitate the budgetary arrangements of institutions unable to purchase the complete set of volumes from their 1958 budgets. Until January 31, the thirty-three volumes of the English edition may be ordered for 435 American dollars, £155 sterling, or 1,860 Swiss francs. The special pre-publication price for the complete set represents a saving of some 70 dollars as compared with the regular price of the set. For the French and Spanish editions, each of which is expected to include approximately fifteen volumes, the special pre-publication price will be 190 U.S. dollars, $£ 68$ sterling, or 815 Swiss francs. If the number of volumes is less than fifteen, proportionate refunds will be made to subscribers who have ordered a full set. Further information can be obtained from the United Nations, Sales and Circulation (Atomic Energy), United Nations, New York.

The de Havilland Aircraft Co., Ltd.: Appointments

Mr. R. G. McCoy has been appointed general manager of the de Havilland Aircraft Co., Ltd., with effect from December 1. He joined the company in May 1953 as deputy service manager, becoming manager in April 1954, and was responsible for the Service Department until July 1958, as well as acting as assistant to the managing director from January 1956. Mr. D. R. Newman has been appointed chief aerodynamicist of the company with effect from December 1. Mr. M. Herrod-Hempsall remains responsible for administration in the Aerodynamics and allied Departments. Mr. Newman joined the de Havilland Aeronautical Technical School in April 1936 and has been in the Aerodynamics Department since May 1938.

\section{Announcements}

Prof. E. E. Z ZPLER, professor of electronics in the University of Southampton, has been elected president of the British Institution of Radio Engineers for $1958-59$.

Sir Walter Drummond has been appointed chairman of the Farm Buildings Research Committee of the Agricultural Research Council, in succession to Lord Rothschild. The Farm Buildings Research Committee has been set up by the Council to co-ordinate the different research activities concerned with farm buildings and to advise on their further development.

THE 125th meeting of the American Association for the Advancement of Science will be held in Washington, D.C., during December 26-31, with headquarters in the Sheraton-Park Hotel. In addition to the eighteen sections of the Association, about ninety-two affiliated and associated societies will participate. The presidential address, on "Fifty Years of Medical Genetics", will be delivered by Dr. Laurence H. Snyder, president of the University of Hawaii, and retiring president of the Association. Further information can be obtained from Sidney S. Nagus, Medical College of Virginia, Richmond, Virginia.

A Group of experts from Australia, Germany, Iran, Portugal, South Africa, United Kingdom and the United States is meeting, under the auspices of the Food and Agriculture Organization and the Office International des Epizooties, to consider problems of ticks and tick-borne diseases. The meetings are being held during November 24-29, at the Royal College of Veterinary Surgeons in London. Further particulars can be obtained from the Registrar of the College, 9 and 10 Red Lion Square, London, W.C.1.

The 129th course of six Christmas lectures "adapted to a juvenile auditory" will discuss the International Geophysical Year, and is to be delivered at the Royal Institution on December 30, 1958, and January $1,3,6,8$ and 10,1959 , at 3 p.m. The lectures are as follows: "The Ionosphere and the International Geophysical Year", by J. A. Ratcliffe ; "Geomagnetism", by J. M. Stagg; "Exploration of the Upper Atmosphere", by Dr. R. L. F. Boyd; "Meteorology", by Sir Graham Sutton; "Oceanography in the International Geophysical Year", by Dr. G. E. R. Deacon. Applications for tickets (juveniles, aged 10-17, £1; adult non-members, £2) should be addressed to the Royal Institution, 21 Albemarle Street, London, W.1.

A symposium on "Experimental Approaches to the Problems of Growth and Form in Plants" is being held in the rooms of the Linnean Society of London during December 19-20. This is being arranged by the Experimental Plant Morphology Group of the Society and the Symposium is open to visitors. Further information can be obtained from the Secretaries, Linnean Society, Burlington House, Piccadilly, London, W.1. 